\title{
Evaluation of La-Doped CaO Derived from Cockle Shells for Photodegradation of POME
}

\author{
Siti Shariah Ghazali¹, Wong Ley Kem¹, Rohayu Jusoh¹, Sureena Abdullah ${ }^{1,2}$, \\ Jun Haslinda Shariffuddin $1,2, *$ \\ ${ }^{1}$ Faculty of Chemical and Natural Resources Engineering, Universiti Malaysia Pahang, \\ Lebuhraya Tun Razak 26300 Gambang, Kuantan, Pahang, Malaysia \\ ${ }^{2}$ Centre of Excellence for Advanced Research in Fluid Flow, Universiti Malaysia Pahang, \\ Lebuhraya Tun Razak 26300 Gambang, Kuantan, Pahang, Malaysia
}

Received: 1st October 2018; Revised: 12 ${ }^{\text {nd }}$ January 2019; Accepted: 17th January 2019; Available online: 25th January 2019; Published regularly: April 2019

\begin{abstract}
Photocatalysis has merged to be one of the most promising technology in wastewater remediation. However, the application of photocatalysis in treating palm oil mill effluent (POME) is still limited. Many researches were conducted to explore simple and cost-effective alternatives to replace $\mathrm{TiO}_{2}$ for various industrial purposes. Therefore, the aim of this study is to synthesize and characterize lanthanum doped calcium oxide (La/CaO) as photocatalyst as well as to evaluate the performance of these photocatalysts in the degradation of POME. The photocatalyst used in this study was converted from cockle shells to transform into calcium oxide (CaO) through calcination process. The $\mathrm{CaO}$ produced was doped with $1 \mathrm{wt} \%, 3 \mathrm{wt} \%$, and $5 \mathrm{wt} \%$ of lanthanum (La) using wet impregnation method to enhance its photocatalytic activity. The photocatalysts were characterised using X-ray Diffraction (XRD), Fourier Transform Infrared Spectroscopy (FTIR), Brunauer-Emmett-Teller (BET), Scanning Electron Microscopy (SEM), Energy-Dispersion X-ray (EDX), and Inductively Coupled Plasma Mass Spectrometry (ICPMS). Then, this photocatalyst was performed on POME under UVC in a batch system by using different La/CaO at optimum catalyst dosage of $3.0 \mathrm{~g} / \mathrm{L}$. Through this research, it was found that the POME degradation through photocatalytic reaction was increased with the incorporation of La where $3 \mathrm{wt} \% \mathrm{La} / \mathrm{CaO}$ showed the highest POME degradation compared to others. This is due to the larger BET surface area that provides more active sites resulted from the incorporation of La. The findings of this study imply that the contaminants in POME can be reduced by utilizing $\mathrm{CaO}$ derived from cockle shells. Copyright (C) 2019 BCREC Group. All rights reserved
\end{abstract}

Keywords: Calcium Oxide; Cockle Shell; Palm Oil Mill Effluent; Photodegradation

How to Cite: Ghazali, S.S., Kem, W.L., Jusoh, R., Abdullah, S., Shariffuddin, J.H. (2019). Evaluation of La-Doped $\mathrm{CaO}$ Derived from Cockle Shells for Photodegradation of POME. Bulletin of Chemical Reaction Engineering \& Catalysis, 14 (1): 205-218 (doi:10.9767/bcrec.14.1.3318.205-218)

Permalink/DOI: https://doi.org/10.9767/bcrec.14.1.3318.205-218

\section{Introduction}

In Malaysia, palm oil industry is one of the leading sectors and it contributes significantly to our economic growth. Being one of the world's largest palm oil producer, the industry discharged approximately between 48 to 72 million tonnes and 49 to 74 million tonnes of POME in

* Corresponding Author.

Email: junhaslinda@ump.edu.my (J.H. Shariffuddin), Tel.: +60-9-5492831, Fax: +60-9-5492889
2013 and 2014, respectively [1]. Freely discharged of POME can bring severe impacts to the environment and increase the likelihood of affecting the aquatic life and decreasing the water quality because it contains high level of pollutants such as suspended solid, residual oil and grease, chemical oxygen demand (COD), and biochemical oxygen demand (BOD). At presence, numerous conventional methods have been used in treating POME such as anaerobic digestion [2-5], membrane technology [6-8], and adsorp- 
tion process $[9,10]$. Most of these technologies showed varying level of success. There are also several drawbacks in fully treating POME as it requires high treating cost, consumes large land area, and needs long retention time [1113].

Photocatalysis has shown potentials as one of the treatment methods used in wastewater remediation. This is due to its ability to diminish the pollutants in the wastewater compared to other methods $[14,15]$. The highly reactive hydroxyl radicals generated from heterogeneous photocatalysis can completely oxidize the organic matter contained in the aqueous system with existing of semiconductor photocatalyst. Titanium oxide $\left(\mathrm{TiO}_{2}\right)$ has been used extensively as a photocatalyst in photocatalytic process due to a great potential as a sustainable treatment technology to destruct the contaminants in wastewater [16-18]. However, many researches have been conducted to explore simple, cost-effective and eco-friendly alternatives to replace $\mathrm{TiO}_{2}$ for various industrial purposes such as zinc oxide ( $\mathrm{ZnO})$ [19-21], cadmium sulphide (CdS) [22,23], cerium oxide $\left(\mathrm{CeO}_{2}\right)$ [24,25], and others.

Recently, calcium-based catalysts such as $\mathrm{CaO}$ have attracted special attention due to their low cost with high mechanical stability which made it interesting for removal pollutant matter in wastewater [26,27]. $\mathrm{CaO}$ has been studied and used as the photocatalyst in the treatment/degradation of Rhodamine 6G [28,29], methylene blue [30,31], congo red dye [32], violet GL2B azo dye [33], ammonia [27], and indigo carmine dye [34]. Most of the preparation method to synthesize $\mathrm{CaO}$ are from chemical methods. Therefore, in this study $\mathrm{CaO}$ generated from cockle shell waste is used as alternative and environment friendly photocatalyst. In addition, this can turn the annually increasing waste of cockle shells in Malaysia into a value-added product like calcium oxide and will help to resolve the problems of rising amount of cockle shells.

The additional small amount of doping element like rare earth metals into photocatalyst is used to improve rate of trapping recombination sites of photogenerated electron-hole pairs resulting in the reduction of the quantum efficiency $[21,35,36]$. Lanthanum (La) is chosen as the dopant as it can enhance the photocatalytic reaction and gives varied effects on optical properties [37]. Based on the best of our knowledge, there are very limited research has been done in application of $\mathrm{CaO}$ photocatalyst in POME treatment. Therefore, this research aims to combine the utilization of calcium oxide from cockle shells and incorporate with La rare-earth element for POME remediation through photocatalytic reaction. Through this study, the effect of La loadings in $\mathrm{CaO}$ on the degradation of POME were analysed.

\section{Materials and Methods}

\subsection{Materials}

Cockle shells were collected from local market at Kuantan, Pahang. Pre-treated POME was obtained from pond facultative B at palm oil mill based in Felda Lepar Hilir 3 located at Pahang, Malaysia. Lanthanum nitrate $\left(\mathrm{La}\left(\mathrm{NO}_{3}\right)_{3}\right)$ with $95 \%$ purity was purchased from Sigma-Aldrich was used to be incorporated as a dopant to $\mathrm{CaO}$ formed from waste cockle shells. Deionized water was used in all the experiments that was obtained from Ultra Pure Water Sysyem (Model: Elix 5UV).

\subsection{Preparation of Photocatalyst}

The $\mathrm{CaO}$ from cockle shells was prepared based on Jones et al. [38] and Shariffuddin et al. [39]. Firstly, the cockle shells were cleaned thoroughly using hot water to remove dirt and impurities. After that, the cockle shells were crushed into small particles before they were grinded into powder form using Retsch ZM 200 Grinder. The shells powder was then sieved over a mesh screen to obtain fine powder of less than $63 \mu \mathrm{m}$. The fine powder obtained was transformed into $\mathrm{CaO}$ catalyst via calcination method at $900{ }^{\circ} \mathrm{C}$ for 5 hours in a furnace.

Next, the synthesized $\mathrm{CaO}$ was doped with $1 \mathrm{wt} \%, 3 \mathrm{wt} \%$, and $5 \mathrm{wt} \%$ of La using wet impregnation method. In a typical preparation, $10 \mathrm{~g}$ of $\mathrm{CaO}$ was suspended in $40 \mathrm{~mL}$ of deionized water. To this suspension, $10 \mathrm{~mL} \mathrm{La}\left(\mathrm{NO}_{3}\right)_{3}$ aqueous solution of desired concentration was added. The resulted slurry was stirred for 2 hours without heat and then evaporated to dryness. The precipitate formed was dried overnight in an oven at $120^{\circ} \mathrm{C}$. Lastly, the precipitate was calcined at $400{ }^{\circ} \mathrm{C}$ in furnace with a heating rate of $5^{\circ} \mathrm{C} / \mathrm{min}$ for 3 hours.

\subsection{Characterization of Photocatalyst}

XRD of the photocatalyst were obtained through Bruker D8 Advance X-ray diffractometer operating with a $40 \mathrm{kV}$ in the $2 \theta$ range of $20^{\circ}$ to $80^{\circ}$ with a $0.02^{\circ}$ step size with a $1 \mathrm{~s}$ step time. BET was evaluated based on $\mathrm{N}_{2}$ adsorption-desorption isotherm at $-196^{\circ} \mathrm{C}$ using $\mathrm{Mi}$ cromeretics ASAP 2020 system. Samples were 
degassed at $110^{\circ} \mathrm{C}$ overnight before the $\mathrm{N}_{2}$ adsorption measurements. Then, specific surface areas were calculated from the $\mathrm{N}_{2}$ adsorption data based on BET method using P/Po values between 0.01-0.3.

SEM equipped with EDX were performed to capture the morphology images and to find relative composition and abundance of elements present on the samples using Swift ED3000 in Hitachi TM3030 Plus. The samples were sputter-coated with platinum to prevent charging during the analysis. The functional groups of sample powders were characterized using Nicolet iS5 Model FTIR (Spectrum100) with spectrum collected between the wavenumber of 400 and $4000 \mathrm{~cm}^{-1}$ using OMNIC software. Elemental analysis for $\mathrm{La}$ and $\mathrm{Ca}$ was also determined by ICP-MS (Agilent technologies ICP-MS Model 7700).

\subsection{Photocatalytic Degradation of POME}

Prior starting the degradation experiments, POME sample collected from local palm oil mill was filtered to remove the suspended solids. To ensure the degradation of POME was due to photocatalytic degradation, two sets of control experiments which were photolysis and adsorption were conducted using $\mathrm{CaO}$ and $3 \mathrm{wt} \%$ $\mathrm{La} / \mathrm{CaO}$. Firstly, the suspension was magnetically stirred in the dark to ensure the establishment of the adsorption/desorption equilibrium between photocatalyst and POME at room temperature. The second control experiment was done on evaluating the degradation

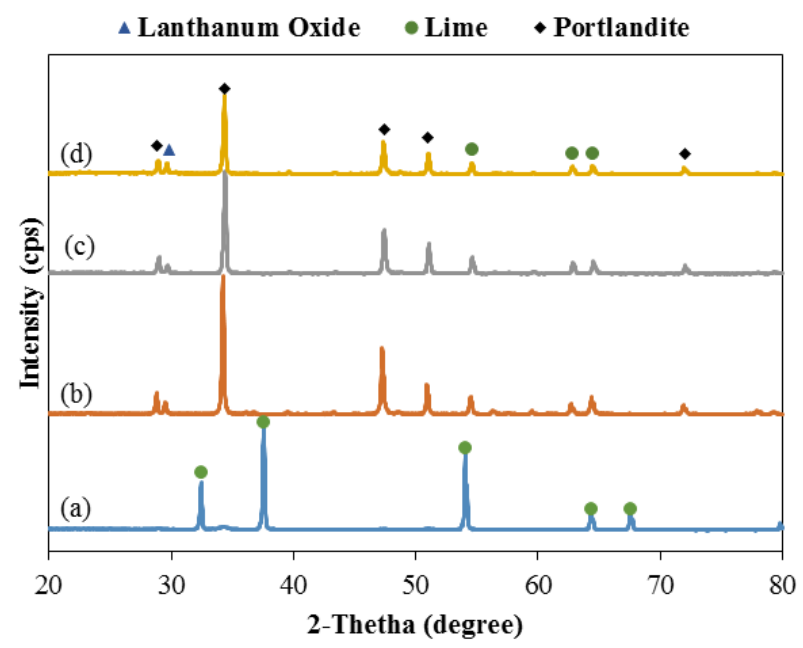

Figure 1. XRD patterns indicating the change in crystal structure and chemical composition of (a) $\mathrm{CaO}$ calcined at $900{ }^{\circ} \mathrm{C}$, (b) $1 \mathrm{wt} \% \mathrm{La} / \mathrm{CaO}$, (c) $3 \mathrm{wt} \% \mathrm{La} / \mathrm{CaO}$ and (d) $5 \mathrm{wt} \% \mathrm{La} / \mathrm{CaO}$. of POME under UVC without presence of photocatalyst to check the ability of photodegrade organic compounds by the UVC.

This was then followed by photocatalytic degradation of POME in the presence of UVC irradiation and $\mathrm{CaO}$ photocatalyst. Firstly, 3 $\mathrm{g} / \mathrm{L}$ of $\mathrm{CaO}$ was added into $200 \mathrm{~mL}$ of diluted POME solution and the suspension was stirred continuously at $300 \mathrm{rpm}$ to keep the mixture in suspension during the photodegradation. After $30 \mathrm{~min}$, the mixture was irradiated with UVC. During the first hour, $2.0 \mathrm{~mL}$ of sample was withdrawn from the reactor vessel at every 15 min interval. While in the next 3 hours, samples were withdrawn at every $30 \mathrm{~min}$ interval. The photodegradation experiments were conducted under limited oxygen condition (no oxygen gas was bubbled into the solution). Prior to analysis, the samples were centrifuged to separate the photocatalyst from POME solution. The COD concentration in POME was then examined using Hach DRB-200 reactor. All digestion solutions would be subjected to the digestion chamber at $150{ }^{\circ} \mathrm{C}$ for $120 \mathrm{~min}$. The experiment was repeated using $\mathrm{La} / \mathrm{CaO}$ photocatalyst of different La loadings at $1 \mathrm{wt} \%, 3$ wt $\%$, and $5 \mathrm{wt} \%$.

\section{Results and Discussion}

\subsection{X-ray Diffraction Studies}

The phase structure of $\mathrm{CaO}$ and $\mathrm{La} / \mathrm{CaO}(1$ $\mathrm{wt} \%, 3 \mathrm{wt} \%$, and $5 \mathrm{wt} \%$ ) were investigated by XRD and shown in Figure 1. The XRD pattern for $\mathrm{CaO}$ in Figure 1(a) shows peaks approximately at $2 \theta=32^{\circ}, 38^{\circ}, 54^{\circ}, 64^{\circ}$, and $68^{\circ}$. All intensified and narrowed peaks were dominated by calcium oxide in cubic phase with apparently no calcium carbonate retained in the form of calcite [40,41]. This is due to the polymorphic transformation of aragonite polymorph to calcium oxide following the calcination process at a temperature of $900{ }^{\circ} \mathrm{C}$ for 5 hours. The XRD patterns of $1 \mathrm{wt} \%, 3 \mathrm{wt} \%$, and 5 wt\% La/CaO (Figure 1(b), (c) and (d)) show peaks of hexagonal portlandite. The existence of portlandite in the samples were due to the conversion of $\mathrm{CaO}$ into $\mathrm{Ca}(\mathrm{OH})_{2}$ during wet impregnation process [42].

The minor peaks indicated by $2 \theta=55^{\circ}, 63^{\circ}$, and $65^{\circ}$ in 1 wt\% La-Ca corresponded to $\mathrm{CaO}$ polymorph [43]. Similarly, the XRD patterns of $\mathrm{La} / \mathrm{CaO}$ for $3 \mathrm{wt} \%$ and $5 \mathrm{wt} \%$ show the same generation of peaks that are related to $\mathrm{CaO}$ polymorph. This shows that, $\mathrm{CaO}$ still exist in $\mathrm{La} / \mathrm{CaO}$ photocatalyst after doping with La elements. The peak intensity of $\mathrm{CaO}$ and $\mathrm{La} / \mathrm{CaO}$ 
are different because additional of La can reduced their degree of crystallinity as reported by Shaveisi et al. [27]. Besides, the diffraction peaks of $\mathrm{La} / \mathrm{CaO}$ in Figure 1 shows the peaks shifted to lowest $2 \theta$ due to lattice expansion [44] which indicated the incorporation of La ion into $\mathrm{CaO}$ lattice structure. Meanwhile, the small peak approximately around $2 \theta=30^{\circ}$ in 1 wt $\%, 3 \mathrm{wt} \%$, and $5 \mathrm{wt} \% \mathrm{La} / \mathrm{CaO}$ were detected to be lanthanum oxide $[45,46]$. The XRD patterns for all the $\mathrm{La} / \mathrm{CaO}$ samples show the absence of lanthanum carbonate as shown in Figure 1(b), (c), and (d).

\subsection{FTIR Spectra of Photocatalyst}

The functional group of photocatalysts produced were analysed using FTIR spectroscopy. Figure 2 shows the FTIR spectra of $\mathrm{CaO}$ and $\mathrm{La} / \mathrm{CaO}$ in the range of $500-3900 \mathrm{~cm}^{-1}$. The bottom spectrum as shown in Figure 2(a) represented the $\mathrm{CaO}$ was calcined at $900{ }^{\circ} \mathrm{C}$. Only a weak band at around $3630 \mathrm{~cm}^{-1}$ was detected and attributed to hydroxyl stretching vibration which appeared resulting from small amount of water adsorbed in the crystalline $\mathrm{CaO}[47,48]$. There are no other impurity peaks related to other groups are observed in this spectrum.

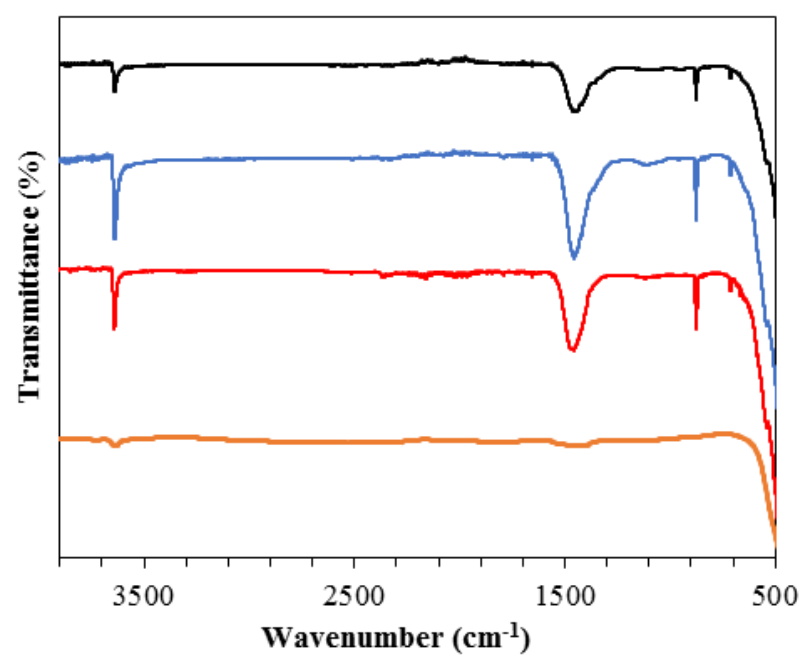

Figure 2. FTIR spectra of (a) $\mathrm{CaO}$ calcined at 900 ${ }^{\circ} \mathrm{C}$, (b) $1 \mathrm{wt} \% \mathrm{La} / \mathrm{CaO}$, (c) $3 \mathrm{wt} \% \mathrm{La} / \mathrm{CaO}$, and (d) 5 wt $\% \mathrm{La} / \mathrm{CaO}$.
The spectra obtained for samples after the calcined shell was incorporated with La ions at $1 \mathrm{wt} \%, 3 \mathrm{wt} \%$, and $5 \mathrm{wt} \%$ were as shown in Figure 2(b), (c), and (d). The sharp intense peaks at $3640 \mathrm{~cm}^{-1}$ in principle can be assigned to $-\mathrm{OH}$ groups which attached to $\mathrm{CaO}$ to form $\mathrm{Ca}(\mathrm{OH})_{2}$ as reported by Shaveisi and Sharifnia [27], and Kaur et al. [42]. This -OH groups was formed due to $\mathrm{CaO}$ was wet impregnated with $\mathrm{La}\left(\mathrm{NO}_{3}\right)_{3}$ solution which showed similar finding with XRD analysis in Figure 1(b), (c), and (d). The two new bands appeared at $1450 \mathrm{~cm}^{-1}$ and $858 \mathrm{~cm}^{-1}$ were corresponded to the peaks of bending vibration of $\mathrm{O}-\mathrm{Ca}-\mathrm{O}$ groups and stretching of $\mathrm{C}-\mathrm{O}$ bond from carbonate [49]. These bands were emerged possibly due to the reaction of photocatalysts with $\mathrm{CO}_{2}$ in the air during sample preparation [50,51]. The minor bands as $\mathrm{M}-\mathrm{O}$ bending vibration within range of $600-800 \mathrm{~cm}^{-1}$ are shown in Figure 2, which $\mathrm{M}$ represents as either $\mathrm{Ca}$ or $\mathrm{La}$ ions which similarly has been reported by Syamsudin et al. [49]. However, Gholami et al. [48] stated that the presence of $\mathrm{La}-\mathrm{O}$ and $\mathrm{Ca}-\mathrm{O}$ in structure at approximately $570 \mathrm{~cm}^{-1}$ which nearly with the result in Figure 2 at around $650 \mathrm{~cm}^{-1}$.

\subsection{Surface Area and Crystallite Size}

The crystallite size of catalysts can be determined from full width of half maximum (FWHM) of the most intense peaks using Scherrer's equation as indicated in Equation (1):

$$
d=\frac{K \lambda}{\beta(\cos \theta)}
$$

Where $d$ is the average of crystal size; $K$ is constant values which related to the shape of the polycrystals $(0.9) ; \lambda$ is the X-ray wavelength of $\mathrm{Cu} \mathrm{K} \alpha$ radiation $(1.5418 \AA) ; \beta$ is FWHM of the XRD peak value and $\Theta_{\beta}$ is the maximum of Bragg's angle in radians [52,53]. By using these data, the estimated crystallite sizes for $\mathrm{CaO}$ and $\mathrm{La} / \mathrm{CaO}$ are shown in Table 1. The crystallite size, $d$ for $\mathrm{CaO}$ sample $(507.44 \mathrm{~nm})$ was found to be larger than $\mathrm{La} / \mathrm{CaO}$. Meanwhile, the crystallite size of

Table 1. Estimated crystallite sizes of photocatalysts and BET specific surface area of the photocatalysts.

\begin{tabular}{lccccc}
\hline \multicolumn{1}{c}{ Sample } & $2 \theta(\mathrm{deg})$ & $\beta(\mathrm{rad})$ & $d(\mathrm{~nm})$ & $\begin{array}{c}\text { BET Specific Surface } \\
\text { Area, } \mathrm{m}^{2} \cdot \mathrm{g}^{-1}\end{array}$ & $\begin{array}{c}\text { Average Pore } \\
\text { Diameter }(\mathrm{nm})\end{array}$ \\
\hline $\mathrm{CaO}$ & 37.57 & 0.0027 & 507.44 & 1.12 & 69.87 \\
$1 \mathrm{wt} \% \mathrm{La} / \mathrm{CaO}$ & 34.24 & 0.0030 & 483.82 & 3.88 & 96.69 \\
$3 \mathrm{wt} \% \mathrm{La} / \mathrm{CaO}$ & 34.41 & 0.0037 & 388.50 & 4.08 & 85.22 \\
$5 \mathrm{wt} \% \mathrm{La} / \mathrm{CaO}$ & 34.41 & 0.0035 & 411.61 & 6.73 & 67.02 \\
\hline
\end{tabular}


$\mathrm{La} / \mathrm{CaO}$ was decreased with increasing of La content up to $3 \%$ and then increased. Previous research by Shakir et al. [20], explained this observation due to expansion of $\mathrm{ZnO}$ lattice caused by radius of $\mathrm{La}^{3+}$ that was larger than $\mathrm{Zn}^{2+}$. Besides, the distortion of lattice structure in $\mathrm{CaO}$ sample occurred when a foreign impurity dopant was introduced. As a result, the nucleation and subsequent growth rate had decreased because the size of $\mathrm{Ca}$ and La ions are different [54].

Table 1 also shows BET specific surface area of the photocatalysts. Based on the results obtained, the BET specific surface area has increased upon the incorporation of lanthanum. This result was consistent with the outcomes of crystallite size obtained from XRD analysis and was in agreement with the literature described by Yang et al. [55]. The increase in BET surface area when increasing dopant percentage can be explained due to the deposited of La that has collectively contributed to the overall BET specific surface area of the $\mathrm{CaO}$ photocatalyst. The higher specific surface area may benefit the photocatalytic activity due to enhanced adsorption of irradiation photons and organic pollutants. Nesic et al. [36] stated that the increasing of La content in $\mathrm{TiO}$ would affect pore diameter by decreasing the diameter. This finding is similar with the result in Table 1 which shows the decreasing of pore diameter with the increasing of La from $1 \mathrm{wt} \%(96.69 \mathrm{~nm}), 3 \mathrm{wt} \%$ $(85.22 \mathrm{~nm})$ and $5 \mathrm{wt} \%(67.02 \mathrm{~nm})$.

\subsection{Morphology and Composition Analysis}

Figure 3 illustrates the surface morphology of undoped $(\mathrm{CaO})$ and $\mathrm{La} / \mathrm{CaO}$ samples studied using SEM. It can be clearly observed from the close-up SEM micrographs that there are
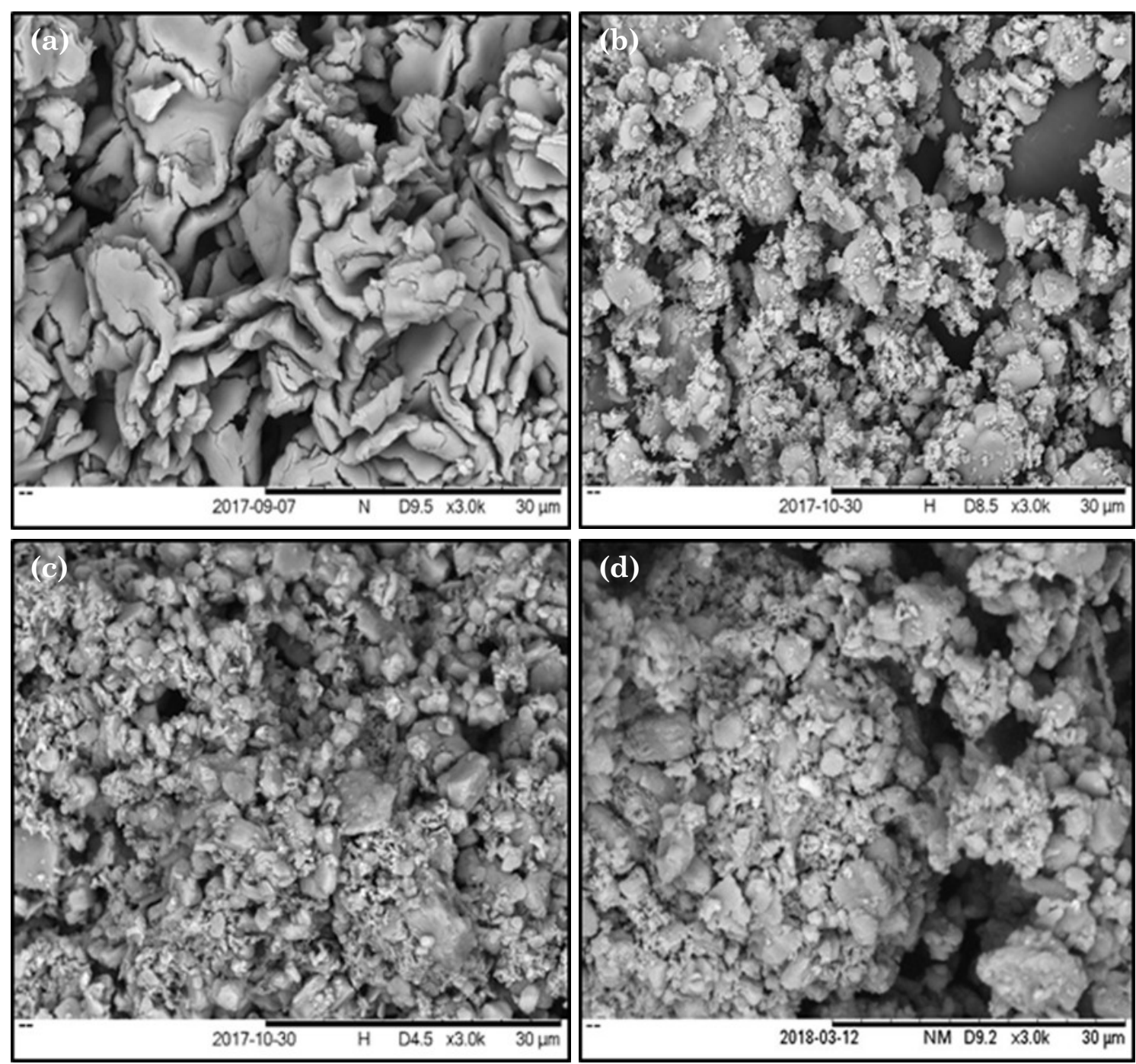

Figure 3. SEM micrographs of (a) $\mathrm{CaO}$ powder calcined at $900{ }^{\circ} \mathrm{C}$, (b) $1 \mathrm{wt} \% \mathrm{La} / \mathrm{CaO}$ powder, and (c) $3 \mathrm{wt} \% \mathrm{La} / \mathrm{CaO}$ powder, (d) $5 \mathrm{wt} \% \mathrm{La} / \mathrm{CaO}$ powder. 

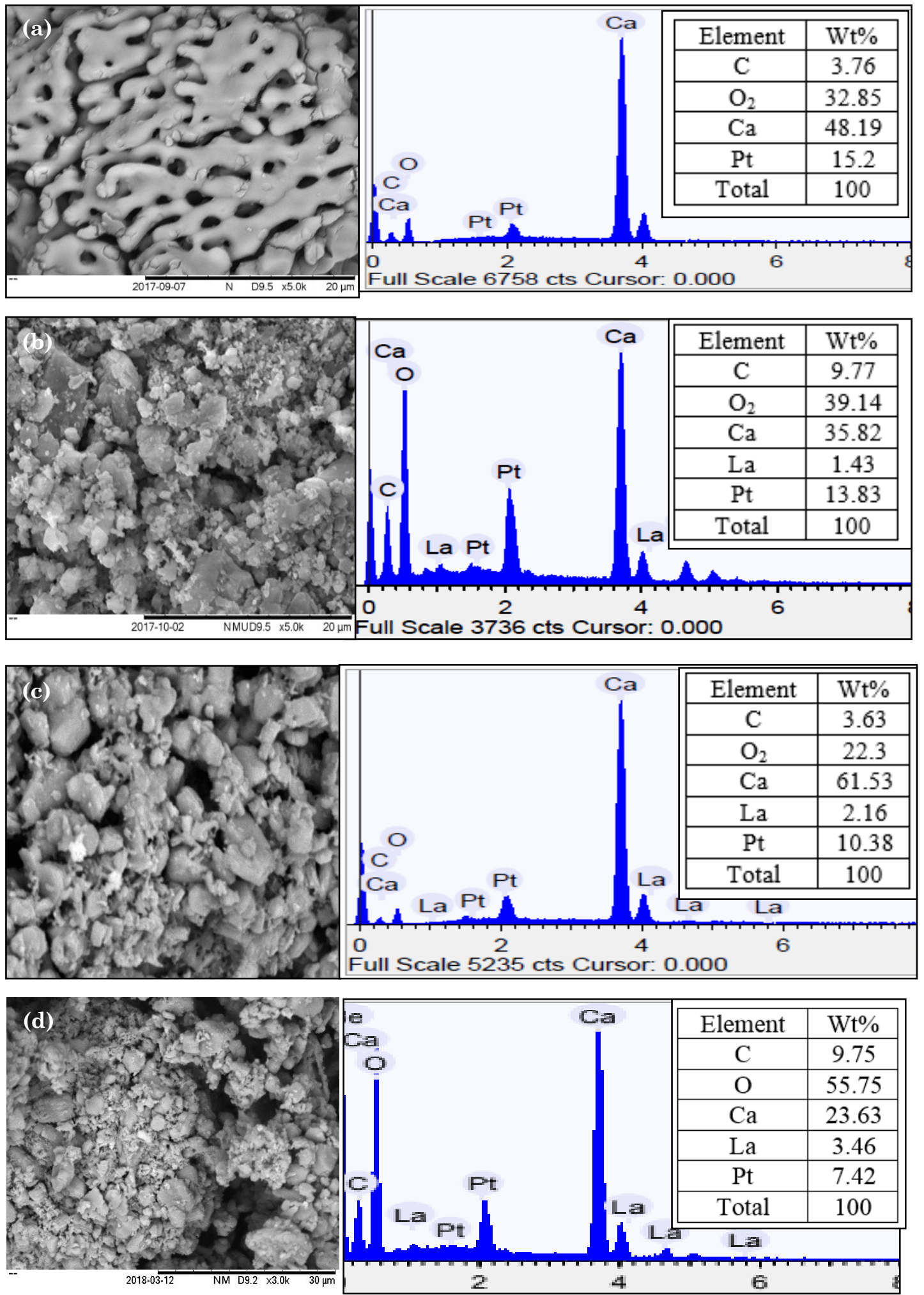

Figure 4. SEM micrographs and EDX spectrum of (a) $\mathrm{CaO}$, (b) $1 \mathrm{wt} \% \mathrm{La} / \mathrm{CaO}$, (c) $3 \mathrm{wt} \% \mathrm{La} / \mathrm{CaO}$ and (d) $5 \mathrm{wt} \% \mathrm{La} / \mathrm{CaO}$. 
structural changes that occur after the incorporation of dopant element in catalyst. The cockle shell powder calcined at $900{ }^{\circ} \mathrm{C}$ is irregular in shape and bonded together as aggregates [56]. Based on Figure 3(a), there are some relief lines on the particle surfaces due to high temperature calcination process. When the calcined shell is further impregnated in lanthanum nitrate solution and activated at $400{ }^{\circ} \mathrm{C}$, the morphologies $\mathrm{La} / \mathrm{CaO}$ photocatalyst of catalyst are demonstrated in Figure 3(b), (c), and (d). The SEM micrograph results show a honeycomblike porous network produced due to the water molecular $\left(\mathrm{H}_{2} \mathrm{O}\right)$ in form of gaseous is released from decomposition of $\mathrm{Ca}(\mathrm{OH})_{2}$ which created large number of voids [57]. Several small particles within the grains were discovered and the crystallites were observed to have no uniform shape. Again, these findings were in good agreement with XRD studies which revealed that the crystallinity of photocatalyst declined when increasing dopant percentage.

Figure 3 also represents the EDX spectra of $\mathrm{CaO}, 1 \mathrm{wt} \% \mathrm{La} / \mathrm{CaO}, 3 \mathrm{wt} \% \mathrm{La} / \mathrm{CaO}$, and $5 \mathrm{wt} \%$ $\mathrm{La} / \mathrm{CaO}$. Based on the EDX analysis as shown in Figure 3 (a), it indicates that calcium element is allocated with highest weight percentage, which is $48.19 \%$, followed by oxygen and carbon. Trace amount of carbon detected in the sample denoted that lime has formed with an

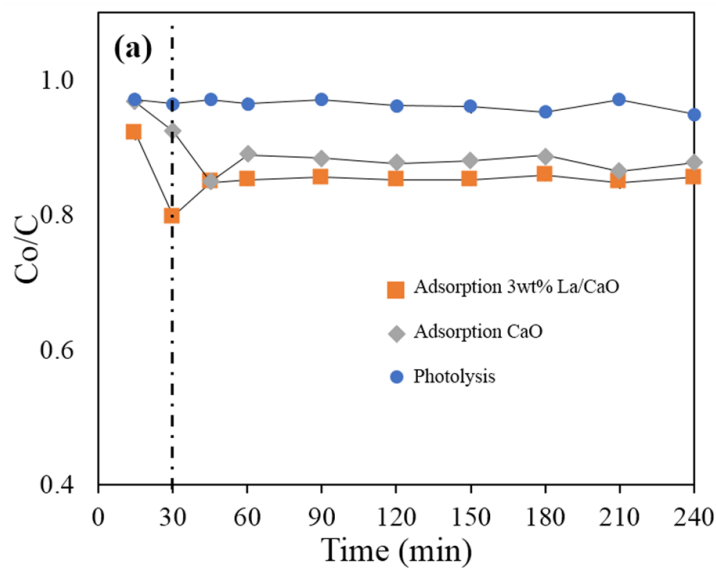

unconverted calcium carbonate residual. Since the quantity of carbon is comparably small, the calcium carbonate peak in the form of calcite has been flattening out in the XRD pattern as shown in Figure 1(a). Meanwhile, to prevent the electrons bombarded during SEM analysis from staying embedded in place where they hit the non-conductive calcined shell, a thin layer of metal was coated on the sample surface [58]. This explained the fact that platinum element presented in the samples as a coating material.

On the other hand, the EDX spectra of $\mathrm{La} / \mathrm{CaO}$ samples as shown in Figure 3 (b), (c), and (d) were observed to exhibit similar elements in $\mathrm{CaO}$, with addition of La element in small amount. The amount of La element presented in $1 \mathrm{wt} \% \mathrm{La} / \mathrm{CaO}, 3 \mathrm{t} \% \mathrm{La} / \mathrm{CaO}$, and 5 $\mathrm{wt} \% \mathrm{La} / \mathrm{CaO}$ were increased to $1.43 \mathrm{wt} \%, 2.16$ $\mathrm{wt} \%$, and $3.46 \mathrm{wt} \%$, respectively. The $\mathrm{wt} \%$ of La in the samples was not the same with the wt\% of dopant due to the dissimilar distribution of La spread in the photocatalyst. However, from the EDX spectra line, it can be concluded that La element was successfully impregnated into the crystal structure of $\mathrm{CaO}$ particles.

Therefore, to verify the exact amount of the $\mathrm{La}$ and $\mathrm{Ca}$ (in ppm) for each sample were analysed by using ICP-MS measurements and listed in Table 2 . The result shows that La ele-

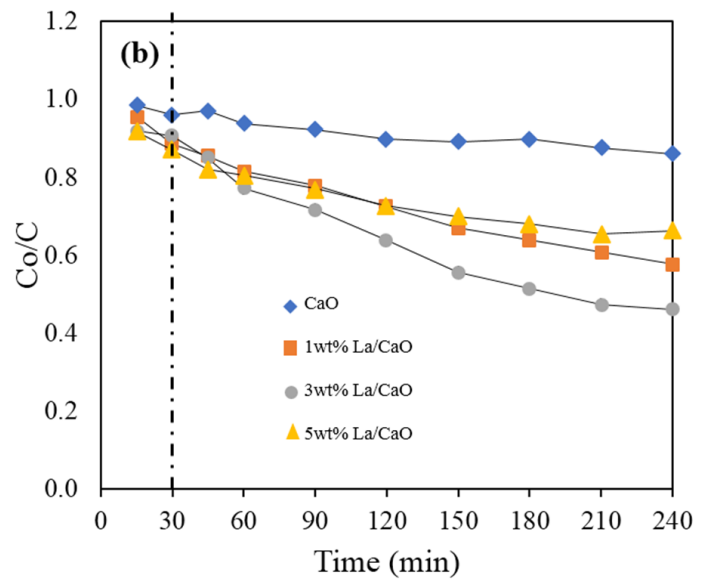

Figure 5. The experiments of POME degradation for (a) control experiment of adsorption at $\mathrm{CaO}$, photolysis for POME and adsorption at $3 \mathrm{wt} \% \mathrm{La} / \mathrm{CaO}$, and $(\mathrm{b})$ the $\mathrm{C}_{\mathrm{o}} / \mathrm{C}$ graph of organic material in POME for photocatalytic degradation over different lanthanum concentration (photocatalyst $=3.0$ $\mathrm{g} / \mathrm{L}$, stirring speed $=300 \mathrm{rpm}, \mathrm{UVC}$, time $=240 \mathrm{~min}$ ).

Table 2. The amount of La and Ca in photocatalysts (in ppm) using ICP-MS

\begin{tabular}{lcccc}
\hline Parameter & $\mathrm{CaO}$ & $1 \mathrm{wt} \% \mathrm{La} / \mathrm{CaO}$ & $3 \mathrm{wt} \% \mathrm{La} / \mathrm{CaO}$ & $5 \mathrm{wt} \% \mathrm{La} / \mathrm{CaO}$ \\
\hline Calcium $(\mathrm{Ca})$ & 134077.0 & 404144.1 & 223793.0 & 505884.5 \\
Lanthanum (La) & - & 4136.7 & 12762.0 & 21285.1 \\
\hline
\end{tabular}



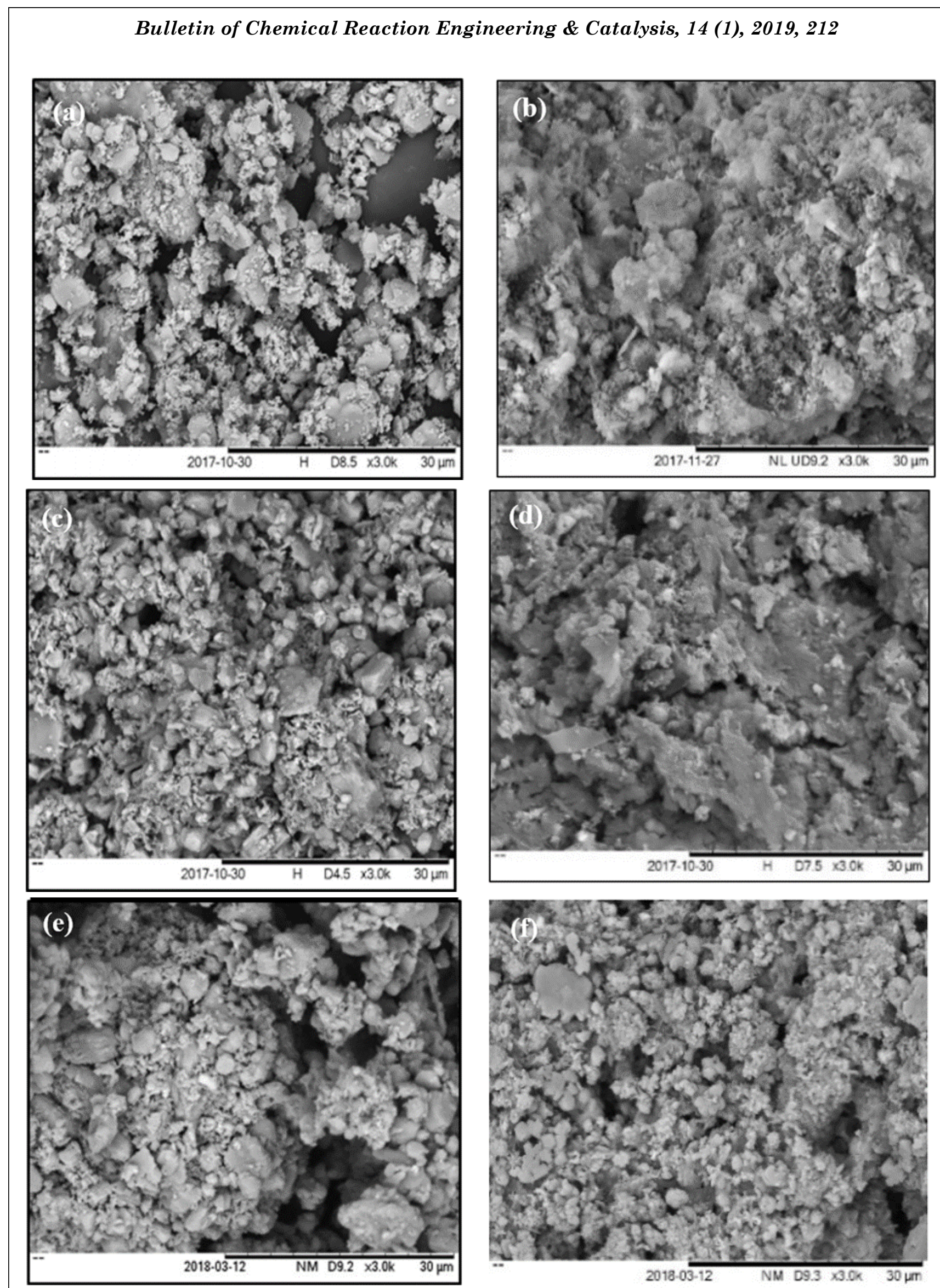

Figure 6. SEM micrographs of photocatalyst (a) $1 \mathrm{wt} \% \mathrm{La} / \mathrm{CaO}$ before photocatalytic treatment, (b) $1 \mathrm{wt} \% \mathrm{La} / \mathrm{CaO}$ after photocatalytic treatment (c) $3 \mathrm{wt} \% \mathrm{La} / \mathrm{CaO}$ before photocatalytic treatment, (d) $3 \mathrm{wt} \% \mathrm{La} / \mathrm{CaO}$ after photocatalytic treatment, (e) $5 \mathrm{wt} \% \mathrm{La} / \mathrm{CaO}$ before photocatalytic treatment, (f) $5 \mathrm{wt} \% \mathrm{La} / \mathrm{CaO}$ after photocatalytic treatment 
ment was present into the catalyst after impregnated. This shows the agreement between the EDX results and ICP-MS measurement on the successful doping of $\mathrm{La}$ into $\mathrm{CaO}$ through wet impregnation method. From the ICP-MS results, it is shown that the amount of La increase as expected.

\subsection{Effect of Lanthanum Concentration}

Before starting the experiment, blank run experiments were conducted to ensure the degradation of $\mathrm{POME}$ is due to potocatalytic degradation. Therefore, Figure 4 (a) and (c) shows the adsorption process by using $\mathrm{CaO}$ and $3 \mathrm{wt} \%$ $\mathrm{La} / \mathrm{CaO}$ where the maximum POME degradation after 30 min was about $10.9 \%$ and 13.73 $\%$, respectively. After that, the reaction was re- mained constant for the rest of reaction time (240 min). Therefore, adsorption can be regarded as negligible since the degradation is in minimal percentage presumably a minor for POME removal mechanism. This maximum removal of POME during the adsorption (dark condition) within $30 \mathrm{~min}$ has interpreted that the experiments was necessity to start stirred in the dark for at least $30 \mathrm{~min}$ before photocatalytic reaction undertaken next remaining of process time. The photolysis result in Figure 4 (b) shows no degradation occurred during the reaction time studied. Therefore, the removal of organic substances in POME by photolysis is insignificant. Hence, photolysis alone will not able to degrade the POME.

In this study, La was chosen as a dopant materials due to its ability to enhance the
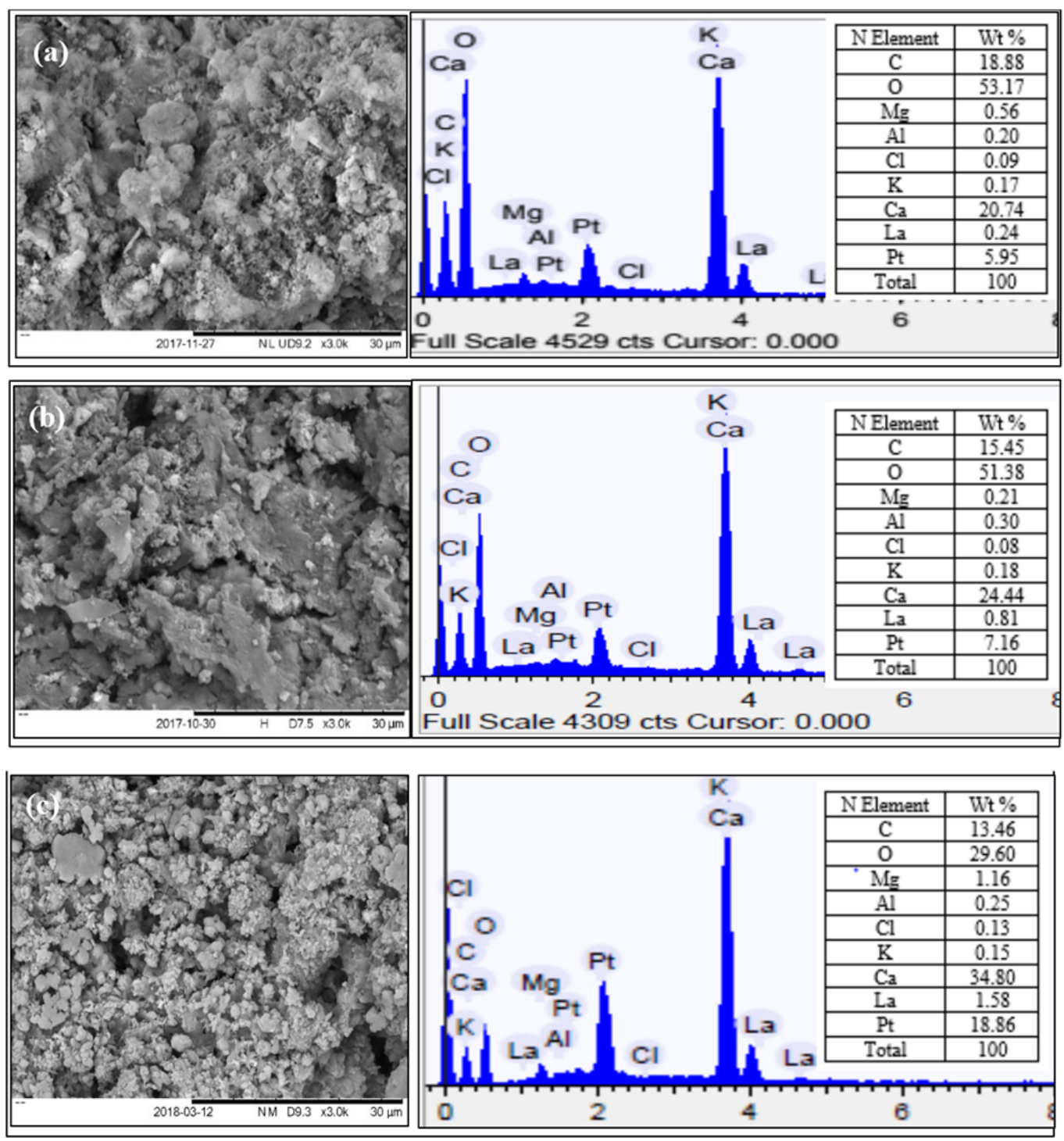

Figure 7. EDX spectrum of (a) $1 \mathrm{wt} \% \mathrm{La} / \mathrm{CaO}$ photocatalyst after photocatalytic treatment, (b) 3 wt $\% \mathrm{La} / \mathrm{CaO}$ photocatalyst after photocatalytic treatment, (c) $5 \mathrm{wt} \% \mathrm{La} / \mathrm{CaO}$ photocatalyst after photocatalytic treatment. 
photocatalyst properties as reported in other studies by Nesic et al. [59] and Thi \& Lee [60]. Figure 5(b) shows the degradation of POME by using different type of La loadings. The removal of organic substances in POME by using $\mathrm{CaO}$ shows the lowest degradation compared to other photocatalysts. Subsequently, when increasing the percentage of La in the photocatalyst, the removal of pollutants in POME through photocatalysis has increased significantly. It can be clearly seen that when $\mathrm{CaO}$ was doped with $1 \mathrm{wt} \%, 3 \mathrm{wt} \%$, and $5 \mathrm{wt} \%$ of La, the COD concentration was reduced by $43.4 \%$, $54.0 \%$, and $33.9 \%$, respectively. The increase in the degradation with the increment of $\mathrm{La}$ loadings is possibly due to the lattice deformation that occurred after dopant ions $\left(\mathrm{La}^{3+}\right)$ were introduced which could hinder the recombination of electron-hole pairs and therefore enhance the photoactivity [61-63]. In addition, the incorporation of $\mathrm{La}$ ions have increased the BET specific surface area as shown in Table 1, thus allowing an extensive amount of organic compounds adsorbed on the photocatalyst sur-
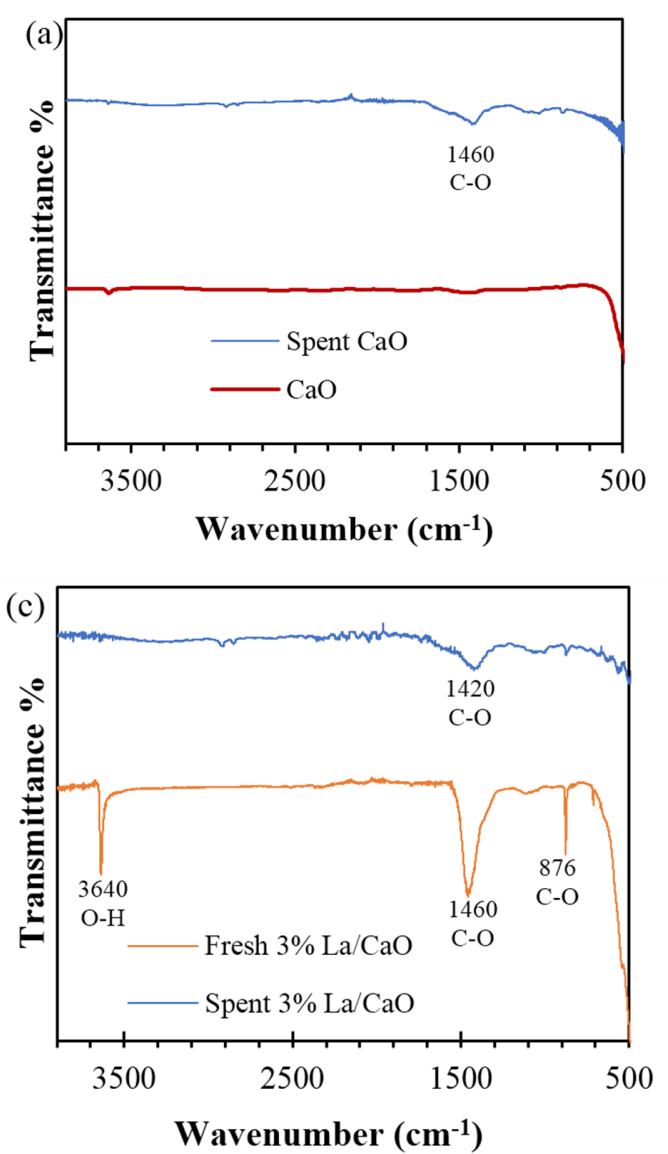

face. On the other hand, the reduction of photocatalytic degradation for $5 \mathrm{wt} \% \mathrm{La} / \mathrm{CaO}$ may be due to the excess doping metal into photocatalyst which created recombination center for photogenerated charge carriers [37].

\subsection{Characterization of Spent Photocatalysts}

Figure 6 demonstrates the morphology of 1 wt $\%, 3 \mathrm{wt} \%$, and $5 \mathrm{wt} \%$ of $\mathrm{La} / \mathrm{CaO}$ photocatalyst respectively before and after the photocatalytic treatment. By comparing the morphology of spent catalyst to the freshly prepared catalyst in Figure 6, it was found that the spent catalyst consists of irregular shapes and various sizes distribution which are in tiny aggregates. Meantime, the microstructure of spent photocatalyst appeared to be less porous due to the adsorption of organic pollutants in POME onto the active sites of photocatalyst.

The elemental composition of $1 \mathrm{wt} \%, 3$ wt $\%$, and $5 \mathrm{wt} \% \mathrm{La} / \mathrm{CaO}$ spent catalysts are shown in Figure 6 (a), (b), and (c), respectively. The presence of additional magnesium $(\mathrm{Mg})$, aluminium ( $\mathrm{Al})$, chlorine $(\mathrm{Cl})$, and potassium
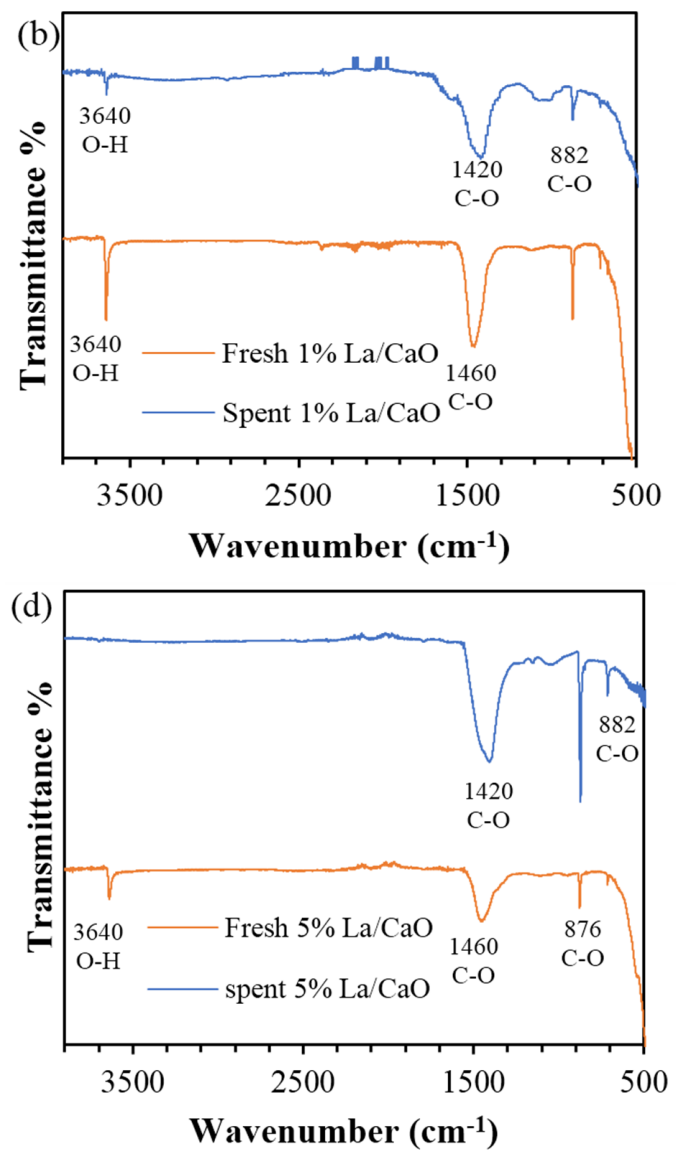

Figure 7. EDX spectrum of (a) $1 \mathrm{wt} \% \mathrm{La} / \mathrm{CaO}$ photocatalyst after photocatalytic treatment, (b) 3 $\mathrm{wt} \% \mathrm{La} / \mathrm{CaO}$ photocatalyst after photocatalytic treatment, (c) $5 \mathrm{wt} \% \mathrm{La} / \mathrm{CaO}$ photocatalyst after photocatalytic treatment. 
(K) elements in the spent doped photocatalysts indicate that the degradation intermediates of POME were attached to the catalyst surface during photoreaction. This is parallel with statement by Rupani et al. [64] which described POME as a viscous brownish liquid that contains substantial amount of minerals such as $\mathrm{Mg}, \mathrm{Al}, \mathrm{K}$, and so forth. Moreover, chlorine which act as a highly efficient disinfectant may have added into POME to poison the diseasecausing pathogens and also came from the freshwater used in the processing of palm oil. This explained the fact that chlorine was detected in the EDX spectrum in small amount, which is less than $0.1 \mathrm{wt} \%$.

Comparative FTIR spectra of the catalysts before and after photocatalytic treatment with POME are shown in Figure 7. It was observed that the FTIR spectra of $1 \mathrm{wt} \%, 3 \mathrm{wt} \%$, and 5 wt $\%$ of spent $\mathrm{La} / \mathrm{CaO}$ in Figure 7 (a), (b), and (c), retained almost similar patterns for the functional groups $(\mathrm{C}-\mathrm{O}$ and $\mathrm{O}-\mathrm{H})$ as the freshly prepared $\mathrm{La} / \mathrm{CaO}$ photocatalyst even after the photoreaction. However, the FTIR spectra for spent and fresh $\mathrm{CaO}$ (Figure 7 (a)), shows there are changes in terms of the patterns and functional groups. This shows that by doping the $\mathrm{CaO}$ with $\mathrm{La}$, the photocatalyst are much more stable compared to the undoped $(\mathrm{CaO})$. In addition, comparative spectra for the doped fresh and spent photocatalysts reveal that the significant changes in these sample powders are the changes in the intensity of the functional groups $(\mathrm{C}-\mathrm{O}$ and $\mathrm{O}-\mathrm{H})$. It can be observed that, these functional groups decreased after the photocatalytic reactions. The decreased in intensity of the functional groups indicates that these groups are being photodissolved in order to allow a greater amount of oxygen from the lattice to participate in the degradation of POME to form $\mathrm{OH}$ radicals where this mechanism also is known as Mars Van Krevelen mechanism. Similar results were reported by Ali et al. [62] on the degradation of methylene blue using $\mathrm{ZnO}$ as a photocatalyst.

\section{Conclusions}

Four samples of photocatalysts were successfully synthesized using $\mathrm{CaO}$ derived from cockle shells by adding La as dopant to treat POME through photocatalytic reaction. The results showed that POME was successfully degraded with $3 \mathrm{wt} \% \mathrm{La} / \mathrm{CaO}$ functioned most effectively, followed by $5 \mathrm{wt} \%, 1 \mathrm{wt} \%$ of $\mathrm{La} / \mathrm{CaO}$, and $\mathrm{CaO}$ photocatalysts. It was observed that the degradation of POME increased with the increment of La loading where the maximum degradation occurred at $3 \mathrm{wt} \% \mathrm{La} / \mathrm{CaO}$. The results from XRD concluded that the incorporation of $\mathrm{La}$ into $\mathrm{CaO}$ showed lower crystallinity and crystallite size, while from BET results showed that higher surface area was produced with the increment of $\mathrm{La}$ as dopant. These results showed that the incorporation of La provided more active sites for photocatalytic reaction. The emerging of this finding is believed to be able to recover and recycle cockle shells in huge amount while providing an environmentfriendly solution to wastewater remediation system. From this study, although $\mathrm{La} / \mathrm{CaO}$ can be used as an alternative material for photocatalyst, the degradation rate is not as efficient compared to $\mathrm{TiO}_{2}$. Therefore, further study will be needed to improve the performance of $\mathrm{La} / \mathrm{CaO}$ as a photocatalyst.

\section{Acknowledgments}

The authors acknowledge Ministry of Higher Education (MoHE), Malaysia for the financial support through Fundamental Research Grant Scheme (FRGS) no. RDU160153.

\section{References}

[1] Ding, G.T., Yaakob, Z., Takriff, M.S., Salihon, J., Abd Rahaman, M.S. (2016). Biomass production and nutrients removal by a newlyisolated microalgal strain Chlamydomonas $\mathrm{sp}$ in palm oil mill effluent (POME). International Journal of Hydrogen Energy, 41: 48884895.

[2] Najafpour, G., Zinatizadeh, A., Mohamed, A., Isa, M.H., Nasrollahzadeh, H. (2006). Highrate anaerobic digestion of palm oil mill effluent in an upflow anaerobic sludge-fixed film bioreactor. Process Biochemistry, 41: 370-379.

[3] Poh, P., Chong, M. (2009). Development of anaerobic digestion methods for palm oil mill effluent (POME) treatment. Bioresource Technology, 100: 1-9.

[4] Chan, Y.J., Chong, M.F., Law, C.L. (2011). Optimization on thermophilic aerobic treatment of anaerobically digested palm oil mill effluent (POME). Biochemical Engineering Journal, 55: 193-198.

[5] Malakahmad, A., Chuan, S.Y. (2013). Application of response surface methodology to optimize coagulation-flocculation treatment of anaerobically digested palm oil mill effluent using alum. Desalination and Water Treatment, 51: 6729-6735.

[6] Ahmad, A.L., Ismail, S., Bhatia, S. (2003). Water recycling from palm oil mill effluent (POME) using membrane technology. Desalination, 157: 87-95. 
[7] Wu, T.Y., Mohammad, A.W., Jahim, J. Md., Anuar, N. (2007). Palm oil mill effluent (POME) treatment and bioresources recovery using ultrafiltration membrane: Effect of pressure on membrane fouling. Biochemical Engineering Journal, 35: 309-317.

[8] Ahmad, A.L., Ismail, S., Bhatia, S. (2005). Membrane treatment for palm oil mill effluent: Effect of transmembrane pressure and crossflow velocity. Desalination, 179: 245-255.

[9] Mohammed, R.R., Ketabchi, M.R., McKay, G. (2014). Combined magnetic field and adsorption process for treatment of biologically treated palm oil mill effluent (POME). Chemical Engineering Journal, 243: 31-42.

[10] Ahmad, A.L., Sumathi, S., Hameed, B.H. (2005). Adsorption of residue oil from palm oil mill effluent using powder and flake chitosan: equilibrium and kinetic studies. Water Research, 39: 2483-94.

[11] Ng, K.H., Cheng, C.K. (2016). Photo-polishing of POME into $\mathrm{CH}_{4}$-lean biogas over the UVresponsive $\mathrm{ZnO}$ photocatalyst. Chemical Engineering Journal, 300: 127-138.

[12] Ng, K.H., Lee, C.H., Khan, M.R., Cheng, C.K. (2016). Photocatalytic degradation of recalcitrant POME waste by using silver doped titania: Photokinetics and scavenging studies. Chemical Engineering Journal, 286: 282-290.

[13] Tan, Y.H., Goh, P.S., Lai, G.S., Lau, W.J., Ismail, A.F. (2014). Treatment of Aerobic Treated Palm Oil Mill Effluent (AT-POME) by using $\mathrm{TiO}_{2}$ Photocatalytic Process. Jurnal Teknologi, 70(2): 61-63

[14] Bello, M.M., Raman, A.A.A. (2017). Trend and current practices of palm oil mill effluent polishing: Application of advanced oxidation processes and their future perspectives. Journal Environment Management, 198: 170-182.

[15] Ng, K.H., Cheng, C.K. (2015). A novel photomineralization of POME over UVresponsive $\mathrm{TiO}_{2}$ photocatalyst: Kinetics of POME degradation and gaseous product formations. RSC Advances, 5: 53100-53110.

[16] Han, F., Kambala, V.S.R., Srinivasan, M., Rajarathnam, D., Naidu, R. (2009). Tailored titanium dioxide photocatalysts for the degradation of organic dyes in wastewater treatment: A review. Applied Catalysis A: General, 359: 25-40.

[17] Agustina, T.E., Ang, H., Vareek, V. (2005). A review of synergistic effect of photocatalysis and ozonation on wastewater treatment. Journal of Photochemistry and Photobiology C: Photochemistry Reviews, 6: 264-273.

[18] Chong, M.N., Jin, B., Chow, C.W., Saint, C. (2010). Recent developments in photocatalytic water treatment technology: a review. Water Research, 44: 2997-3027.
[19] Khodami, Z., Nezamzadeh-Ejhieh, A. (2015). Investigation of photocatalytic effect of $\mathrm{ZnO}-$ $\mathrm{SnO} 2 /$ nano clinoptilolite system in the photodegradation of aqueous mixture of 4methylbenzoic acid/2-chloro-5-nitrobenzoic acid. Journal of Molecular Catalysis A: Chemical, 409: 59-68.

[20] Shakir, M., Faraz, M., Sherwani, M.A., AlResayes, S.I. (2016). Photocatalytic degradation of the Paracetamol drug using Lanthanum doped $\mathrm{ZnO}$ nanoparticles and their invitro cytotoxicity assay. Journal of Luminescence, 176: 159-167.

[21] Korake, P.V., Dhabbe, R.S., Kadam, A.N., Gaikwad, Y.B., Garadkar, K.M. (2014). Highly active lanthanum doped $\mathrm{ZnO}$ nanorods for photodegradation of metasystox. Journal of Photochemistry and Photobiology B: Biology, 130: 11-19.

[22] Yan, H., Yang, J., Ma, G., Wu, G., Zong, X., Lei, Z., Shi, J., Li, C. (2009). Visible-lightdriven hydrogen production with extremely high quantum efficiency on $\mathrm{Pt}-\mathrm{PdS} / \mathrm{CdS}$ photocatalyst. Journal of Catalysis, 266: 165168.

[23] Kadam, A.N., Dhabbe, R.S., Kokate, M.R., Garadkar, K.M. (2014). Room temperature synthesis of CdS nanoflakes for photocatalytic properties. Journal of Materials Science: Material in Electronics, 25: 1887-1892.

[24] Mena, E., Rey, A., Rodríguez, E.M., Beltrán, F.J. (2017). Nanostructured $\mathrm{CeO} 2$ as catalysts for different AOPs based in the application of ozone and simulated solar radiation. Catalysis Today, 280: 74-79.

[25] Kumar, P.M., Josephine, S.G.A., Sivasamy, A. (2017). Oxidation of organic dye using nanocrystalline rare earth metal ion doped $\mathrm{CeO} 2$ under UV and Visible light irradiations. Journal of Molecular Liquids, 242: 789797.

[26] Sánchez-Cantú, M., Peralta, L.R.M. A., Galindo-Rodríguez, B., Puente-López, E., Rubio-Rosas, E., Gómez, C.M., Tzompantzi, F. (2017). Calcium-containing materials as alternative catalysts in advanced oxidation process. Fuel, 198: 76-81.

[27] Shaveisi, Y., Sharifnia, S. (2018). Deriving $\mathrm{Ag}_{3} \mathrm{PO}_{4} \mathrm{CaO}$ composite as a stable and solar light photocatalyst for efficient ammonia degradation from wastewater. Journal of Energy Chemistry, 27: 290-299.

[28] Bhaskar, N.S., Kadam, A.D., Biwal, J.J., Diwate, P.M., Dalbhanjan, R.R., Mahale, D.D., Hinge, S.P., Banerjee, B.S., Mohod, A.V., Gogate, P.R. (2015). Removal of Rhodamine 6G from wastewater using solar irradiations in the presence of different additives. Desalination and Water Treatment, 57:18275-18285. 
[29] Kornprobst, T., Plank, J. (2012). Photodegradation of Rhodamine B in Presence of $\mathrm{CaO}$ and NiO-CaO Catalysts. International Journal of Photoenergy, 2012: 1-6.

[30] Ameta, R., Kumar, D., Jhalora, P. (2014). Photocatalytic degradation of methylene blue using calcium oxide. Acta Chimica Pharmaceutica Indica, 4: 20-28.

[31] Song, L., Zhang, S., Chen, B., Sun, D. (2009). Highly active $\mathrm{NiO}-\mathrm{CaO}$ photocatalyst for degrading organic contaminants under visiblelight irradiation. Catalysis Communications, 10: 421-423.

[32] Anantharaman, A., Ramalakshmi, S., George, M. (2016). Green synthesis of calcium oxide nanoparticles and its applications. International Journal of Engineering Research and Application, 6: 27-31.

[33] Madhusudhana, N., Yogendra, K., Mahadevan, K.M. (2012). A comparative study on Photocatalytic degradation of Violet GL2B azo dye using $\mathrm{CaO}$ and $\mathrm{TiO}_{2}$ nanoparticles. International Journal of Engineering Research and Applications, 2: 1300-1307.

[34] Veeranna, K., Lakshamaiah, M.T., Narayan, R.T. (2014). Photocatalytic degradation of indigo carmine dye using calcium oxide. International Journal of Photochemistry, 2014: 1-6.

[35] Shinde, S.S., Bhosale, C.H., Rajpure, K.Y. (2013). Kinetic Analysis of Heterogeneous Photocatalysis: Role of Hydroxyl Radicals. Catalysis Reviews, 55: 79-133.

[36] Nešić, J., Manojlović, D.D., Anđelković, I., Dojčinović, B.P., Vulić, P.J., Krstić, J., Roglić, G.M. (2013). Preparation, characterization and photocatalytic activity of lanthanum and vanadium co-doped mesoporous $\mathrm{TiO}_{2}$ for azodye degradation. Journal of Molecular Catalysis A: Chemical, 378: 67-75.

[37] Arif, H.S., Murtaza, G., Hanif, H., Ali, H.S., Yaseen, M., Khalid, N.R. (2017). Effect of La on structural and photocatalytic activity of SnO 2 nanoparticles under UV irradiation. Journal of Environmental Chemical Engineering, 5: 3844-3851.

[38] Jones, M., Wang, L., Abeynaike, A., Patterson, D.A. (2011). Utilisation of waste material for environmental applications: calcination of mussel shells for waste water treatment. $A d$ vances in Applied Ceramics, 110: 280-286.

[39] Shariffuddin, J.H., Jones, M.L., Patterson, D.A. (2013). Greener photocatalysts: Hydroxyapatite derived from waste mussel shells for the photocatalytic degradation of a model azo dye wastewater. Chemical Engeering Research and Design, 91: 1693-1704.

[40] Taufiq-Yap, Y., Lee, H., Hussein, M., Yunus, R. (2011). Calcium-based mixed oxide cata- lysts for methanolysis of Jatropha curcas oil to biodiesel. Biomass and Bioenergy, 35: 827834.

[41] Safaei-Ghomia, J., Ghasemzadeha, M.A., Mehrabi, M. (2013). Calcium oxide nanoparticles catalyzed one-step multicomponent synthesis of highly substituted pyridines in aqueous ethanol media. Scientia Iranica, 20: 549-554.

[42] Kaur, M., Ali, A. (2011). Lithium ion impregnated calcium oxide as nano catalyst for the biodiesel production from karanja and jatropha oils. Renewable Energy, 36: 2866-2871.

[43] Kaur, M., Ali, A. (2014). Ethanolysis of waste cottonseed oil over lithium impregnated calcium oxide: Kinetics and reusability studies. Renewable Energy, 63: 272-279.

[44] Naidu, B.S., Vishwanadh, B., Sudarsan, V., Vatsa, R.K. (2012). BiPO $_{4}$ : a better host for doping lanthanide ions. Dalton Transactions, 41: 3194-203.

[45] Teo, S.H., Goto, M., Taufiq-Yap, Y.H. (2015). Biodiesel production from Jatropha curcas L. oil with $\mathrm{Ca}$ and $\mathrm{La}$ mixed oxide catalyst in near supercritical methanol conditions. The Journal of Supercritical Fluids, 104: 243-250.

[46] Yan, S., Kim, M., Salley, S.O., Ng, K.S. (2009) Oil transesterification over calcium oxides modified with lanthanum. Applied Catalysis A: General, 360: 163-170.

[47] Reyero, I., Arzamendi, G., Gandía, L.M. (2014). Heterogenization of the biodiesel synthesis catalysis: $\mathrm{CaO}$ and novel calcium compounds as transesterification catalysts. Chemical Engineering Research and Design, 92: 1519-1530.

[48] Gholami, Z., Abdullah, A.Z., Lee, K.T. (2014). Heterogeneously catalyzed etherification of glycerol to diglycerol over calciumlanthanum oxide supported on MCM-41: A heterogeneous basic catalyst. Applied Catalysis A: General, 479: 76-86.

[49] Syamsuddin, Y., Murat, M.N., Hameed, B.H. (2015). Transesterification of Jatropha oil with dimethyl carbonate to produce fatty acid methyl ester over reusable $\mathrm{Ca}-\mathrm{La}-\mathrm{Al}$ mixedoxide catalyst. Energy Conversion and Management, 106: 1356-1361.

[50] Mahesh, S.E., Ramanathan, A., Begum, K.M.S., Narayanan, A. (2015). Biodiesel production from waste cooking oil using $\mathrm{KBr}$ impregnated $\mathrm{CaO}$ as catalyst. Energy Conversion and Management, 91: 442-450.

[51] Gholami, Z., Abdullah, A.Z., Lee, K.-T. (2013). Glycerol etherification to polyglycerols using $\mathrm{Ca} 1+\mathrm{xAl1}-\mathrm{xLaxO}_{3}$ composite catalysts in a solventless medium. Journal of the Taiwan Institute of Chemical Engineers, 44: 117-122. 
[52] Wang, C.C., Lee, C.K., Lyu, M.D., Juang, L.C. (2008). Photocatalytic degradation of C.I. Basic Violet 10 using $\mathrm{TiO}_{2}$ catalysts supported by $\mathrm{Y}$ zeolite: An investigation of the effects of operational parameters. Dyes and Pigments, 76: 817-824.

[53] Dhahri, R., Leonardi, S.G., Hjiri, M., Mir, L.E., Bonavita, A., Donato, N., Iannazzo, D., Neri, G. (2017). Enhanced performance of novel calcium/aluminum co-doped zinc oxide for $\mathrm{CO} 2$ sensors. Sensors and Actuators B: Chemical, 239: 36-44.

[54] Sharma, P.K., Dutta, R.K., Pandey, A.C. (2009). Doping dependent room-temperature ferromagnetism and structural properties of dilute magnetic semiconductor $\mathrm{ZnO}: \mathrm{Cu}^{2+}$ nanorods. Journal of Magnetism and Magnetic Materials, 321: 4001-4005.

[55] Yang, X., Cao, C., Erickson, L., Hohn, K., Maghirang, R., Klabunde, K. (2009). Photocatalytic degradation of Rhodamine $\mathrm{B}$ on $\mathrm{C}$-, S-, $\mathrm{N}$-, and Fe-doped $\mathrm{TiO}_{2}$ under visible-light irradiation. Applied Catalysis B: Environmental, 91: 657-662.

[56] Buasri, A., Chaiyut, N., Loryuenyong, V., Worawanitchaphong, P., Trongyong, S. (2013). Calcium oxide derived from waste shells of mussel, cockle, and scallop as the heterogeneous catalyst for biodiesel production. The Scientific World Journal, 2013: 1-7.

[57] Hu, S., Wang, Y., Han, H. (2011). Utilization of waste freshwater mussel shell as an economic catalyst for biodiesel production. Biomass Bioenergy, 35: 3627-3635.

[58] Dunlap, M., Adaskaveg, J.E., (1997). Introduction to the Scanning Electron Microscope, Theory, Practice, and Procedures. Facility for Advanced Instrumention, U.C. Davis.

[59] Nešić, J., Manojlović, D.D., Anđelković, I., Dojčinović, B.P., Vulić, P.J., Krstić, J., and Roglić, G.M. (2013). Preparation, characterization and photocatalytic activity of lanthanum and vanadium co-doped mesoporous $\mathrm{TiO}_{2}$ for azo-dye degradation. Journal of Molecular Catalysis A: Chemical, 378: 67-75.
[60] Thi, V.H.-T., Lee, B.-K. (2017). Effective photocatalytic degradation of paracetamol using La-doped $\mathrm{ZnO}$ photocatalyst under visible light irradiation. Material Research Bulletin, 96: 171-182.

[61] Lan, X., Wang, L., Zhang, B., Tian, B., Zhang, J. (2014). Preparation of lanthanum and boron co-doped $\mathrm{TiO}_{2}$ by modified sol-gel method and study their photocatalytic activity. Catalyst Today, 224: 163-170.

[62] Al-Salim, N.I., Bagshaw, S.A., Bittar, A., Kemmitt, T. A, McQuillan, A.J, Mills, A.M., Ryan, M.J. (2000). Characterisation and activity of sol-gel-prepared TiO2 photocatalysts modified with $\mathrm{Ca}, \mathrm{Sr}$ or $\mathrm{Ba}$ ion additives. Journal of Material Chemistry, 10: 23582363.

[63] Bahruji, H., Bowker, M., Davies, P.R., Morgan, D.J., Morton, C.A., Egerton, T.A., Kennedy, J., Jones, W. (2014). Rutile $\mathrm{TiO}_{2}-\mathrm{Pd}$ Photocatalysts for Hydrogen Gas Production from Methanol Reforming. Topics in Catalysis, 58: 70-76.

[64] Rupani, P.F., Singh, R.P., Ibrahim, M.H., Esa, N. (2010). Review of current palm oil mill effluent (POME) treatment methods: vermicomposting as a sustainable practice. World Applied Sciences Journal, 11: 70-81.

[65] Adeleke, A.O., Latiff, A.A.A., Al-Gheethi, A.A., Daud, Z. (2017). Optimization of operating parameters of novel composite adsorbent for organic pollutants removal from POME using response surface methodology. Chemosphere, 174: 232-242.

[66] Saleh, T.A., Gupta, V.K., Al-Saadi, A.A. (2013). Adsorption of lead ions from aqueous solution using porous carbon derived from rubber tires: experimental and computational study. Journal of Colloid Interface Science, 396: 264-269.

Selected and Revised Papers from The $4^{\text {th }}$ International Conference of Chemical Engineering \& Industrial Biotechnology (ICCEIB 2018) (http://icceib.ump.edu.my/index.php/en/) (Universiti Malaysia Pahang, by 1 1t-2nd August 2018) after Peer-reviewed by Scientific Committee of ICCEIB 2018 and Peer-Reviewers of Bulletin of Chemical Reaction Engineering \& Catalysis 